\title{
PODATNOŚĆ PRZEDSIĘBIORSTWA NA KRYZYS - KONCEPCJA OSTRZEGANIA PRZED ZAGROŻENIEM WYSTĄPIENIA KRYZYSU W PRZEDSIĘBIORSTWIE
}

\begin{abstract}
Zmienność otoczenia przyczynia się do konieczności definiowania nowego podejścia do oceny zagrożeń działalności podmiotu. Obecnie kluczową jest ocena dokonywana na podstawie wyłącznie jednego rodzaju danych (danych finansowych). Wydaje się to być niewystarczające i obciążone zbyt dużym ryzykiem błędu, co do definiowania zagrożenia funkcjonowania przedsiębiorstwa. Diagnozowane w ten sposób zagrożenia upadłością czy pogorszenia kondycji przedsiębiorstwa opiera się na danych odzwierciedlających w sprawozdaniach finansowych przeszłe zdarzenia gospodarcze, nie uwzględniając obecnej - bieżącej sytuacji przedsiębiorstwa, która w stosunku do sytuacji z przeszłości może być diametralnie inna, gorsza lub lepsza. Konieczne jest dostosowywanie modeli i systemów diagnostycznych do interdyscyplinarnego charakteru przedsiębiorstw oraz do możliwości badania bieżącej sytuacji przedsiębiorstwa. Diagnozowanie złego stanu przedsiębiorstwa w oparciu tylko o dane historyczne jest obecnie sytuacją optymalną mogącą jednak przyczynić się do podejmowania błędnych decyzji zarządczych zarządów tych przedsiębiorstw, jak i ich interesariuszy. Ustalenie stanu przed powstaniem zagrożenia upadłością lub pogorszeniem kondycji, przyczynić się może do zwiększenia efektywności podejmowanych decyzji biznesowych i działań wyprzedających przez zarządy tych firm, jak i partnerów biznesowych. Zdefiniowanie pojęcia podatności przedsiębiorstwa na kryzys oraz narzędzi pozwalających na ocenę stopnia podatności przedsiębiorstwa na kryzys wydaje się być alternatywą dla modeli oceny zagrożenia przedsiębiorstw upadłością, analiz finansowych, analiz strategicznych czy analiz sprzedażowych. Stworzenie mechanizmu, który będzie analizował i diagnozował kompleksowo zasoby podmiotu uwzględniając wartości jakościowe i ilościowe w ujęciu historycznym, bieżącą sytuację przedsiębiorstwa oraz jego plany i możliwości w kontekście otoczenia gospodarczego może przyczynić się do poprawienia m.in. jakości zarządzania przedsiębiorstwem.
\end{abstract}

Słowa kluczowe: zarządzanie przedsiębiorstwem, podatność na kryzys, zagrożenie finansowe, kryzys przedsiębiorstwa, definicja podatności na kryzys.

\section{WPROWADZENIE}

Zróżnicowane otoczenie, zintensyfikowana jego zmienność oraz przyczyniające się do tego szybkie zmiany w postrzeganiu i ocenie wartości zasobów organizacji powodują konieczność tworzenia wydajnych metod i sposobów identyfikacji zagrożeń dotyczących funkcjonowania przedsiębiorstwa zarówno dla przedsiębiorstwa, jak i jego interesariuszy. Dotychczasowe podejście, w którym definiuje się moment zagrożenia upadłością przed-

\footnotetext{
${ }^{1}$ Mgr Marek Sochoń - Reuter Consulting, ul. Okrzei 51a, lok 2010, 96-300 Żyrardów; e-mail: marek.sochon@interia.pl
} 
siębiorstwa lub opracowuje metody i schematy wyjścia przedsiębiorstwa z kryzysu wydaje się być niewystarczające dla zwiększania bezpieczeństwa procesów zachodzących podczas obrotu gospodarczego, w szczególności tych związanych z kredytowaniem podmiotów charakteryzujących się wysoką podatnością na kryzys.

Funkcja dyskryminacyjna Altmana, jako jeden z pierwszych modeli badania zagrożenia upadłością, wydaje się w obecnej rzeczywistości gospodarczej za mało precyzyjnym podejściem, aby móc właściwie i w odpowiednim momencie dokonać oceny przedsiębiorstwa. Interesariusze, podczas podejmowania decyzji związanych z zaangażowaniem środków własnych, muszą odpowiedzieć na pytania: czy warto inwestować w przedsiębiorstwo i jakie jest ryzyko niepowodzenia inwestycji? Natomiast menedżerowie przedsiębiorstw w procesie gospodarowania powinni podejmować właściwe decyzje w kontekście kondycji podmiotu i jego zasobów, co do dalszej działalności lub jej zaniechania czy też odpowiedniego dostosowania do istniejących warunków.

Turbulentne otoczenie gospodarcze, to nowa jakościowo rzeczywistość, w której nastąpiło rozdzielenie gospodarki realnej od sfery finansowej (kryzys finansowy w 2007 roku), co przyczyniało się i przyczynia do konieczności szukania nowego podejścia do oceny przedsiębiorstwa pod kątem jego szans na przetrwanie lub rozwój czy też badania kondycji przedsiębiorstw.

Bankructwa i upadłości przedsiębiorstw z długoletnimi tradycjami i osiągnięciami, wskazują na konieczność badania podatności podmiotów gospodarczych na kryzys. Podatność ta oznacza, że przedsiębiorstwo jest narażone na znalezienie się w sytuacji kryzysowej, której następstwem może być kryzys w przedsiębiorstwie, a w konsekwencji upadłość i likwidacja firmy. Skrajne przykłady kryzysów takich zagranicznych liderów jak np. Nokia, Kodak, czy rodzimych potentatów w swoich branżach jak Gant S.A. i DSG S.A. oraz spektakularnych sukcesów tak znanych marek jak: Google, Twitter, Facebook, powodują konieczność znalezienia odpowiedzi na pytanie: jakie cechy podmiotu są oznaką podatności przedsiębiorstwa na kryzys, który może prowadzić do upadłości i bankructwa? W rozważaniu tego problemu badawczego może być pomocna identyfikacja cech podmiotów, które okazały się odporne na kryzys i osiągnęły sukces.

Modele przedsiębiorstw wzorcowych, które odniosły sukces na rynku, są opisywane w literaturze przedmiotu. Nie określa się jednak w literaturze przedmiotu metod, które pozwalają zmierzyć odporność przedsiębiorstwa na kryzys ${ }^{2}$. Natomiast w przypadku problemu podatności przedsiębiorstw na kryzys w literaturze przedmiotu wskazuje się głównie wzorce i analizy przedsiębiorstw, które poniosły porażkę, na przykład w kontekście efektu zarażania ${ }^{3}$. Nadal jednak niewiele jest metod i modeli służących do badania podatności przedsiębiorstwa na kryzys.

Mając na uwadze fakt, że każde przedsięwzięcie gospodarcze związane jest z dwiema głównymi kategoriami - potencjalnym powodzeniem i niepowodzeniem realizacji - naukowcy powinni przede wszystkim zdefiniować i opracować modele służące do badania źródeł i przyczyn potencjalnego niepowodzenia - inaczej ujmując kryzysu. Takie podejście wydaje się być w pełni uzasadnione, gdyż zgodnie z tezą głoszoną przez A. Carnegie

\footnotetext{
${ }^{2}$ M. Romanowska, Odporność przedsiębiorstwa na kryzys, Studia i prace Kolegium Zarządzania i Finansów, z. 118, SGH, Warszawa 2012, s. 8.

${ }^{3}$ S. Wyciślak, Efekt zarażania a działalność organizacji, Kraków 2013, s. 7.
} 
„,zadbaj przede wszystkim o koszty, a zyski same zadbają o siebie”4, opracowanie modelu diagnozowania podatności przedsiębiorstwa na kryzys może zmienić sytuację przedsiębiorstw, jak również przyczynić się do minimalizowania ich strat.

Celem artykułu jest zdefiniowanie koncepcji pojęcia podatności przedsiębiorstwa na kryzys, co może być punktem wyjścia do opracowania szczegółowej definicji i narzędzia diagnostycznego badającego podatność przedsiębiorstw na kryzys. Zastosowaną metodą badawczą $\mathrm{w}$ artykule jest analiza literatury przedmiotu oraz rozważania autora oparte na metodzie dedukcji.

\section{ISTOTA KRYZYSU}

Przedmiotami rozważań w niniejszym opracowaniu są przedsiębiorstwa, które powstały w celu generowania zysku. Przedsiębiorstwa działające na rynku są, co do zasady, w większości przypadków powoływane w celu osiągania korzyści, w związku z realizowanymi celami, zgodnie z ich zdefiniowanymi: wizją i misją. Podczas realizacji wizji i misji zachodzi jednak wiele zmian (zdarzeń i procesów) niezależnych od przedsiębiorstwa, które wcześniej nie mogły być przewidziane, a które mogą przyczynić się do wystąpienia problemów na drodze realizacji powyższych założeń. Zaistniałe problemy w niektórych przypadkach doprowadzają do powstania sytuacji kryzysowych, a w konsekwencji do kryzysu. Jednoznaczne stwierdzenie, czy przedsiębiorstwo jest w kryzysie, czy też w sytuacji kryzysowej jest problematyczne i trudne do zidentyfikowania w związku z różnorodnością interpretacji pojęcia kryzysu i sytuacji kryzysowej w przedsiębiorstwie.

W literaturze przedmiotu pojęciem sytuacji kryzysowej nazywa się zbiór okoliczności, które doprowadziły do kryzysu ${ }^{5}$. Powyższa definicja wskazuje granicę, w której przedsiębiorstwo z sytuacji kryzysowej przechodzi w stan kryzysu.

W literaturze przedmiotu kryzys jest opisywany w różnych konwencjach, jako konsekwencja pewnych zdarzeń, etap w rozwoju przedsiębiorstwa, patologia czy proces zachodzący w przedsiębiorstwie:

- kryzys jako stan przedsiębiorstwa - stan taki zagraża przetrwaniu firmy, realizacji jej celów, ogranicza czas potrzebny na podjęcie działań zaradczych i zaskakuje decydentów swoim pojawieniem się, stwarzając w ten sposób warunki silnej presjít. Kryzys w przedsiębiorstwie jest traktowany jako sytuacja wielkiego zagrożenia organizacji jako całości, w której na skutek spiętrzenia się różnorodnych trudności i nasilenia zjawisk konfliktowych zagrożona jest realizacja jej podstawowych funkcji ${ }^{7}$. Stan przedsiębiorstwa, w którym wyraźnie rysuje się jego zagrożenie finansowe można nazwać stanem kryzysu. Zagrożenie finansowe firmy (financial distress, corporate insolvency) to termin, który wszyscy rozumiemy, a jednocześnie trudno go precyzyjnie zdefiniować. W mikroekonometrii finansowej znane są modele upadłości, dla których podstawą jest dychotomiczna kategoria bankructwa

${ }^{4}$ A. Zelek, Zarzadzanie kryzysem w przedsiębiorstwie. Perspektywa strategiczna, Warszawa 2003, s. 85.

${ }^{5}$ Z. Kral, A. Zabłocka-Kluczka, O istocie zjawisk kryzysowych organizacji [w:] Zachowania organizacji wobec zjawisk kryzysowych, red. J. Skalik, Wrocław 2003, s. 18.

${ }^{6}$ Ch.F. Hermann, Some Consequences of Crisis chich limit The Viability of Organizations, Administrative Science Quarterly 1963, No. 8.

${ }^{7}$ B. Wawrzyniak (red.), Zarzadzanie w kryzysie. Koncepcje, badania, propozycje, Warszawa 1984, s. 58. 
firmy. W sprawie zagrożenia finansowego na ogół zgadzamy się, że bankructwo jest sytuacją ostateczną, a całkowite zdrowie przedsiębiorstwa - sytuacją najlepszą. Pomiędzy nimi znajduje się obszar potencjalnego zagrożenia finansowego ${ }^{8}$. Kryzys w przedsiębiorstwie to sytuacja bądź stan, w którym wskutek spiętrzenia się trudności zagrożona jest realizacja podstawowych funkcji przedsiębiorstwa przy jednoczesnym ograniczeniu zdolności organizacji do zlikwidowania zaistniałych sytuacji lub stanu. Badania sytuacji kryzysowych w przedsiębiorstwach prowadzą do wniosku, że przyczyny ich tkwią w braku umiejętności identyfikacji zagrożeń pojawiających się w otoczeniu i wykorzystania szans w tym otoczeniu. To prowadzi do braku reakcji i niedostosowania przedsiębiorstwa do zmian;

- kryzys jako następstwo związane ze zdarzeniami występującymi w przedsiębiorstwie lub jego otoczeniu - kryzys jest wynikiem nieplanowanych zdarzeń zakłócających lub zagrażających normalnemu funkcjonowaniu firmy ${ }^{10}$. Kryzysem jest każde wydarzenie lub działanie, które może mieć potencjalnie negatywne oddziaływanie na wiarygodność i sprawność biznesu i co jest typowe - pozostaje lub wkrótce będzie poza kontrolą tego biznesu ${ }^{11}$. Kryzys to główne, nieprzewidywalne wydarzenie, które ma potencjalnie negatywne efekty, znacząco ograniczające działalność organizacji ${ }^{12}$. Kryzys jest efektem pojawienia się nieoczekiwanych zakłóceń w działalności organizacji, w tym czynników wewnętrznych i zewnętrznych o losowym charakterze ${ }^{13}$. Kryzys to konsekwencja zakłóceń w istnieniu lub w realizacji jednego lub kilku czynników determinujących egzystencję i rozwój przedsiębiorstwa, zarówno tych o oddziaływaniu z zewnątrz, jak i tych wewnętrznych, zależnych od sprawności zarządzania ${ }^{14}$;

- kryzys jako etap rozwoju - kryzys pojawia się w przedsiębiorstwie wówczas, gdy dotychczasowy model organizacyjny nie zapewnia już dalszego efektywnego funkcjonowania $^{15}$. Kryzys organizacji oznacza punkt zwrotny w jej cyklu życia i ma krytyczne znaczenie dla jej przetrwania. Wynika z sytuacji przekształcenia się szans w zagrożenia ${ }^{16}$. Kryzys jest w zasadzie nieuchronną fazą rozwoju przedsiębiorstwa, poprzedzającą jego bankructwo lub sanację, z szansami na sukces rynkowy i finansowy ${ }^{17}$. Kryzys jest jedną $\mathrm{z}$ faz $\mathrm{w}$ organizacyjnym rozwoju przedsiębiorstwa, a jego pojawienie się stanowi dla organizacji nową jakościowo sytuację organizacyjną ${ }^{18}$

8 M. Gruszczyński, Empiryczne finanse przedsiębiorstw, Warszawa 2015, s. 132.

9 G. Gierszewska, Strategie kryzysowe w warunkach globalizacji [w:] Praktyka zarzadzania kryzysem $w$ przedsiębiorstwie, red. B. Kozyra, A. Zelek, Szczecin 2002, s. 15.

${ }^{10}$ R. Oldcorn, Management, London 1989, p. 237.

11 J.R. Caponigro, The Crisis Counselor. A step by step Guide to Managing a Business Crisis, NTX 2000, p. 5.

12 R.M. Barton, Crisis Managament, Oxford Press Publishers, Oxford 1993, p. 12.

${ }^{13}$ I.I. Mitroff, Managing Crisises before The hapten, NY 2001, p. 5.

14 A. Zelek, Zarzadzanie kryzysem w przedsiębiorstwie. Perspektywa strategiczna, Warszawa 2003, s. 34.

15 M. Czerska, Organizacja przedsiębiorstw. Metodologia zmian organizacyjnych, Wyd. UG, Gdańsk 1996, s. 10.

16 A. Zelek, Zarzadzanie kryzysem w przedsiębiorstwie..., s. 33.

17 Ibidem, s. 33.

18 Ibidem, s. 40. 
- kryzys jako patologia rozwoju przedsiębiorstwa - kryzys jest patologią rozwoju przedsiębiorstwa, spowodowaną często dysproporcjami między celami i zasobami do ich osiągnięcia. Kryzys jako sytuacja patologiczna zagraża bytowi ekonomicznemu przedsiębiorstwa ${ }^{19}$. Kryzys w przedsiębiorstwie polega na splocie nasilających się dysfunkcji wewnętrznych, wynikających zarówno z charakteru struktur wewnętrznych przedsiębiorstwa (wykształconych w warunkach regulacji nierynkowej) i ich niedopasowaniu do warunków otoczenia, jak też błędów w zarządzaniu $^{20}$;

- kryzys jako proces zachodzący w przedsiębiorstwie - czyli ciąg zdarzeń przebiegających w określonym czasie, będących zagrożeniem dla egzystencji przedsiębiorstwa, ale również uniemożliwiającym tę egzystencję ${ }^{21}$. Kryzys przedsiębiorstwa to proces uwarunkowany pasmem zdarzeń i sytuacji zsynchronizowanych w pewnym przedziale czasowym, a w konsekwencji prowadzący do dysfunkcji podstawowych działań przedsiębiorstwa ${ }^{22}$;

- kryzys jako element ryzyka - ryzyko uwzględnia pozytywne i negatywne wyniki. Tę dualność określa chiński symbol. Jest on połączeniem niebezpieczeństwa (kryzysu) oraz szansy, określających złą oraz dobrą stronę ryzyka ${ }^{23}$.

Z przytoczonych definicji wynika, że w zdecydowanej większości kryzys jest stanem lub zdarzeniem o charakterze pejoratywnym, który powinien $\mathrm{w}$ przedsiębiorstwie być zdiagnozowany najszybciej jak to jest możliwe. W obecnym turbulentnym otoczeniu, permanentnie zmieniającej się rzeczywistości korzystniejszym z perspektywy zarządzania staje się nabycie umiejętności unikania kryzysów w przedsiębiorstwie lub zapobiegania ich wystąpieniu niż ich diagnozowania. Z tej perspektywy stworzenie właściwego narzędzia pozwalającego diagnozować podatność przedsiębiorstwa na kryzys, które będzie stosowane do badania podmiotów gospodarczych może przyczynić się do zmniejszenia ilości bankructw i upadłości.

\section{DEFINICJA PODATNOŚCI PRZEDSIĘBIORSTWA NA KRYZYS}

Model diagnozowania podatności przedsiębiorstwa na kryzys może wzmocnić przedsiębiorstwa poprzez identyfikację ich niepożądanych cech (w konsekwencji mogących doprowadzić do kryzysu i jego negatywnych następstw) oraz wskazanie kierunków ich eliminowania.

Teoretyczny model podatności firmy na kryzys w 1978 r. przedstawiony został przez C.F. Smart, W.A. Thompson, I. Vertinsky. „Model ten opisuje cechy przedsiębiorstwa mające wpływ na wrażliwość i podatność organizacji na kryzys. Wprawdzie jest to model teoretyczny niebazujący na obserwacjach empirycznych, ale zasługuje na zainteresowanie, ponieważ próbuje powiązać efektywność rynku oraz podatność firmy na kryzys z następującymi trzema grupami zmiennych przyczynowych:

${ }^{19}$ E. Urbanowska-Sojkin, Zarzqdzanie przedsiębiorstwem. Od kryzysu do sukcesu, Poznań 1999, s. 20.

${ }^{20}$ A. Zelek, Zarządzanie kryzysem w przedsiębiorstwie..., s. 34.

${ }^{21}$ K. Zimniewicz, Nauka o organizacji i zarządzaniu, Warszawa 1990, s. 223 i n.

${ }^{22}$ M. Rochoń, Efektywność restrukturyzacji finansowej przedsiębiorstw. Analiza komparatywna instrumentarium wspierajacego proces restrukturyzacji finansowej przedsiębiorstw na przyktadzie Polski i USA, Szczecin 2006, s. 30.

23 A. Damodaran, Ryzyko strategiczne. Podstawy zarzadzania ryzykiem, Warszawa 2009, s. 34. 
- zmienne konkurencyjne i środowiskowe (decyzje dotyczące rynku danego produktu, cykle koniunkturalne itp.);

- cechy kadry zarządzającej, takie jak indywidualne możliwości czy stosowne style zarządzania;

- atrybuty organizacyjne, takie jak zasoby i struktury"24.

Autorzy modelu nie stworzyli definicji pojęcia podatności przedsiębiorstwa na kryzys, lecz zdefiniowali w kontekście sprecyzowanych zmiennych przyczynowych profile przedsiębiorstw w zależności od rodzaju środowisk, w których przedsiębiorstwa mogą funkcjonować. „Model ten opisuje profile przedsiębiorstw najlepiej pasujących do pięciu różnych środowisk rynkowych: stabilnego, słabnącego, rozwijającego się, cyklicznego oraz nieciągłego (rozwijającego się, ale $\mathrm{z}$ nieoczekiwanymi i ostrymi załamaniami)"25.

W rozprawie doktorskiej z 2015 r. A.H. Dębicka przedstawiła wyniki badań przeprowadzonych na grupie małych i średnich przedsiębiorstw związanych z badaniem podatności tych przedsiębiorstw na sytuację kryzysową. W swojej pracy autorka nie zdefiniowała pojęcia podatności przedsiębiorstwa na sytuację kryzysową czy też podatności przedsiębiorstwa na kryzys. Przeprowadzone badania dotyczyły analizy cech, które mogą wpływać na podatność przedsiębiorstwa na kryzys. „W badaniach przeanalizowano następujące cechy, które mogą zwiększać podatność na sytuacje kryzysowe:

- cechy małych i średnich przedsiębiorstw:

$\checkmark \quad$ wielkość przedsiębiorstwa;

$\checkmark$ wiek przedsiębiorstwa;

$\checkmark$ forma prawna przedsiębiorstwa;

$\checkmark$ rodzaj prowadzonej działalności;

- cechy przedsiębiorcy:

$\checkmark$ płeć;

$\checkmark$ wiek;

$\checkmark$ poziom i rodzaj wykształcenia;

$\checkmark \quad$ świadomość podstaw zarządzania sytuacją kryzysową.

Podatność na sytuacje kryzysowe mierzona była jako częstotliwość występowania sytuacji kryzysowych w przedsiębiorstwach według wyodrębnionych $\operatorname{cech}^{26}$. Wyniki badań przeprowadzonych przez A.H. Dębicką zaprezentowano w tabeli 1.

Cecha przedsiębiorstwa, którą jest jego wielkość, okazała się mieć największy wpływ spośród innych badanych cech na powstanie sytuacji kryzysowej w przedsiębiorstwie. Cechy przedsiębiorcy i wyniki badań przedstawiono w tabeli 2 .

Przebadane cechy wskazują na oddziaływanie na powstanie sytuacji kryzysowej jedynie dwóch spośród ośmiu przebadanych cech. Zdefiniowanie podatności przedsiębiorstwa na kryzys w obliczu przedstawionych wyników badań może przyczynić się do stworzenia narzędzi precyzyjniej określających intensywność podatności przedsiębiorstwa na kryzys.

\footnotetext{
${ }^{24}$ S. Slatter, D. Lovett, Restrukturyzacja firmy. Zarzadzanie przedsiębiorstwem $w$ sytuacjach kryzysowych, Warszawa 2001, s. 46.

25 Ibidem, s. 47.

26 A.H. Dębicka, Rozprawa doktorska pt. Zarządzanie sytuacja kryzysowa w matych i średnich przedsiębiorstwach, http://repozytorium.put.poznan.pl/Content/352778/Anna_Helena_Debicka_ Zarzadzanie_sytuacja_kryzysowa_w_malych_i_srednich_przedsiebiorstwach.pdf, s. 109 (dostęp: 06.05.2016 r.).
} 
Tabela 1. Wyniki badań nad wpływem cech przedsiębiorstwa na jego podatność na sytuacje kryzysowe

\begin{tabular}{|l|l|}
\hline \multicolumn{1}{|c|}{ Cecha przedsiębiorstwa } & $\begin{array}{c}\text { Oddziaływanie na powstanie sytuacji } \\
\text { kryzysowej w przedsiębiorstwie }\end{array}$ \\
\hline Wielkość przedsiębiorstwa & Duże \\
\hline Wiek przedsiębiorstwa & Średnie \\
\hline Forma prawna przedsiębiorstwa & Średnie \\
\hline Rodzaj prowadzonej działalności & Średnie \\
\hline
\end{tabular}

Źródło: opracowanie własne na podstawie A.H. Dębicka, Rozprawa doktorska pt. Zarządzanie sytuacją..., s. 119.

Tabela 1. Wyniki badań nad wpływem cech przedsiębiorcy na podatność przedsiębiorstwa na sytuacje kryzysowe

\begin{tabular}{|l|c|}
\hline \multicolumn{1}{|c|}{ Cecha przedsiębiorcy } & $\begin{array}{c}\text { Oddziaływanie na powstanie sytuacji } \\
\text { kryzysowej w przedsiębiorstwie }\end{array}$ \\
\hline Płeć & Brak \\
\hline Wiek & Brak \\
\hline Poziom i rodzaj wykształcenia & Brak \\
\hline $\begin{array}{l}\text { Świadomość podstaw zarządzania } \\
\text { sytuacją kryzysową }\end{array}$ & Duże \\
\hline
\end{tabular}

Źródło: opracowanie własne na podstawie A.H. Dębicka, Rozprawa doktorska pt. Zarzadzanie sytuacją..., s. 119.

Zidentyfikowanie podatności przedsiębiorstwa na kryzys jest niezbędne, by mogło ono uniknąć kryzysu, który - w warunkach negatywnego scenariusza - może doprowadzić do upadłości przedsiębiorstwa, a w konsekwencji do bankructwa. Przyjmując, że faza dojrzałości jest pożądaną fazą w rozwoju dla większości przedsiębiorstw, to w tej fazie w szczególny sposób kryzys może dosięgnąć przedsiębiorstwo. Faza dojrzałości jest dla wielu przedsiębiorstw bardzo trudnym okresem. Najczęściej przedsiębiorstwo na tym etapie funkcjonuje na rynku (w sektorze), który nie ma już istotnego potencjału wzrostu. Walka konkurencyjna pomiędzy poszczególnymi przedsiębiorstwami jest wyjątkowo nasilona. Wszyscy starają się nie utracić swojego udziału w rynku. Brak możliwości zwiększania przychodów w związku z naturalnym rozwojem sektora często prowadzi do wyniszczających wojen cenowych i spadających marż. Na skutek tych działań część przedsiębiorstw, na przykład tych, które mają relatywnie najsłabszą pozycję pod względem kosztów, zaczyna znajdować się pod ogromną presją. To etap w funkcjonowaniu przedsiębiorstwa, kiedy może dojść do poważnego kryzysu, niekiedy przeradzającego się w zagrożenie upadłością lub bankructwo ${ }^{27}$.

W literaturze przedmiotu wyraźnie brakuje metod, wskaźników i modeli pozwalających określić podatność przedsiębiorstwa na kryzys. Zdefiniowane miary i systemy po-

${ }^{27}$ M. Wojtysiak-Kotlarski, Przedsiębiorstwo a ryzyko bankructwa $w$ kontekście doświadczeń gospodarki globalnej. Propozycja konceptualizacji ujęcia teoretycznego na tle przyktadów przedsiębiorstw [w:] Procesy upadtościowe i naprawcze w Polsce na tle doświadczeń Unii Europejskiej, red. E. Mączyńska, Warszawa 2013, s. 91. 
zwalają diagnozować stan kondycji finansowej, kryzys czy też jego zaawansowanie lub zagrożenie upadłością. Wysoki poziom podatności przedsiębiorstwa na kryzys może w konsekwencji doprowadzić przedsiębiorstwo do kryzysu, upadłości, a nawet likwidacji. W związku z powyższym autor przyjmuje, iż opisane w literaturze zagadnienia upadłości mogą wyznaczyć obszary badań nad podatnością przedsiębiorstwa na kryzys. Ocena ryzyka wystąpienia upadłości firmy na rynku konkurencji niedoskonałej zależy od rodzaju przedsiębiorstwa, zapotrzebowania na jego produkty, faktycznych konkurentów, ich reakcji na działalność przedsiębiorstw konkurencyjnych i innych czynników ${ }^{28}$.

W kulturze wewnętrznej najlepiej wyraża się podmiotowość przedsiębiorstwa. W wymiarze kultury można najlepiej ocenić poziom profesjonalizmu i styl pracy kadry kierowniczej, umiejętności i postawy załogi, wewnętrzną organizację i charakter relacji z innymi podmiotami ${ }^{29}$. Przedsiębiorstwo uznane jako jednostka o charakterze podmiotowym składa się $\mathrm{z}$ wielu istotnych sfer, które mają swoją niezależną, ale komplementarną wobec siebie istotę. Jakość tych sfer - materialnej, niematerialnej, relacji wewnętrznych i zewnętrznych - przyczynia się do jakości bytu całego przedsiębiorstwa. Każda z wymienionych sfer posiada adekwatne, przypisane jej atrybuty, m.in. takie jak: adekwatność, intensywność, substytucyjność, komplementarność, indywidualizm, komparatywność. Należy zwrócić uwagę na fakt, że w przedsiębiorstwach występują różne konfiguracje atrybutów w obrębie wymienionych sfer. Odpowiednia konfiguracja atrybutów poszczególnych sfer może przyczynić się do sukcesu przedsiębiorstwa, zaś ich niewłaściwa kombinacja do wystąpienia sytuacji, w której przedsiębiorstwo będzie podatne na kryzys.

Podatność przedsiębiorstwa na kryzys można zatem określić jako sytuację, w której występuje niewłaściwa kombinacja atrybutów jego sfer.

\section{PROPOZYCJA KONCEPCJI SPOSOBU POMIARU PODATNOŚCI PRZEDSIĘBIORSTWA NA KRYZYS}

Kryzys w przedsiębiorstwie jest sytuacją mającą znamiona pozytywne i negatywne. Zgodnie z teorią twórczej destrukcji J.A. Shumpetera, kryzys, jako zdarzenie o ambiwalentnym charakterze, może nie tylko wpłynąć negatywnie na przedsiębiorstwo, ale i przyczynić się do odtworzenia przedsiębiorstwa, nadania mu nowych wartości i funkcji. W praktyce gospodarczej zauważalne jednak jest, że przedsiębiorstwa, w których występuje kryzys, w większości przypadków ulegają negatywnej zmianie jakościowej i ilościowej - pogorszenie ich wyników finansowych związanych m.in. ze spadkiem sprzedaży czy wzrostem kosztów. Autor przyjął w niniejszym artykule stanowisko, że kryzys ma zdecydowanie więcej znamion negatywnych niż pozytywnych, oraz że może prowadzić do upadłości, a w krytycznych przypadkach - do bankructwa rozumianego jako likwidacja podmiotu.

Model pomiaru podatności przedsiębiorstwa na kryzys powinien składać się z odpowiednio dobranych miar o charakterze ilościowym i jakościowym. Ostatecznie wiele czynników wpływa na to, jak przedsiębiorstwo reaguje na wyzwania rynku. Odpowiedź przedsiębiorstwa na bodźce rynkowe kształtuje się na gruncie środowiska działania, jego

${ }^{28}$ M. Pieńkowska, Ujęcie upadtości w teorii przedsiębiorstwa, Materiały i Prace, t. XCII, Instytut Funkcjonowania Gospodarki Narodowej, „Ekonomiczne aspekty upadłości przedsiębiorstw w Polsce”, Szkoła Główna Handlowa, Warszawa 2005, s. 19.

${ }^{29}$ J. Komorowski, Cele przedsiębiorstwa a rozwój gospodarczy. Ujęcie behawioralne, Warszawa 2012, s. 162. 
kultury i etyki. Dlatego na wyzwania rynku przedsiębiorstwa nie reagują w sposób szablonowy, jak wynikałoby to z krzywych popytu i podaży.(...) Czynią to nie tylko kierując się kryteriami ekonomiczno-finansowymi, jak się powszechnie uważa, lecz także w sposób uwzględniający wszystkie wymiary funkcjonowania przedsiębiorstwa, dając wymiar wewnętrznej kulturze ${ }^{30}$. Oparcie się wyłącznie na miarach ilościowych przy budowie modelu służącego do pomiaru podatności przedsiębiorstwa na kryzys ograniczyłoby możliwości skutecznej oceny, gdyż zazwyczaj dane ilościowe odzwierciedlają zdarzenia z przeszłości, a nie ukazują stanu obecnego przedsiębiorstwa czy tez jakościowych aspektów gospodarowania. $\mathrm{Z}$ ilościowym przedstawianiem relacji ekonomicznych, które $\mathrm{z}$ natury są realne, jest trochę tak, jak z opisem rozwoju dziecka sporządzonym na podstawie przyrostu wagi ciała i wzrostu, a nawet pomiaru inteligencji, czy szybkości czytania. Opisując działalność przedsiębiorstwa za pomocą tylko wybranych parametrów ilościowych, nie jesteśmy w stanie odpowiedzieć na podstawowe pytania, a mianowicie, dlaczego jedne przedsiębiorstwa osiągają nadzwyczajne wyniki, inne zaś upadają ${ }^{31}$. Ponadto uwzględnić należy fakt, iż dane jakościowe przedstawiają informacje wskazujące na sposób, w jaki mierzalne efekty gospodarcze są przez przedsiębiorstwo osiągane, tym samym na trwałość i efektywność, z jaką te efekty są osiągane ${ }^{32}$.

Tworząc model badania podatności przedsiębiorstwa na kryzys należy skoncentrować się na czynnikach, elementach czy kompilacjach różnych układów tych elementów i czynników, które zostały zdefiniowane, jako przyczyny kryzysów lub które miały lub mogły mieć wpływ na powstanie kryzysu. Stworzenie katalogu i właściwa ocena istotności poszczególnych czynników przyczyni się do stworzenia modelu służącego do pomiaru podatności przedsiębiorstwa na kryzys. Jednym z przykładów kompilacji różnych elementów i czynników występujących w przedsiębiorstwie jest aspekt istniejącego ładu korporacyjnego, którego jakość została oceniona jako istotna z perspektywy sytuacji ekonomicznej i gospodarczej danego przedsiębiorstwa, a więc również istotna $\mathrm{z}$ perspektywy zaistnienia w przedsiębiorstwie kryzysu. Powszechnie uznaje się, że do przyczyn załamania na rynkach finansowych w Stanach Zjednoczonych i w innych krajach w latach 2007-2008 należą niedostatki nadzoru korporacyjnego (corporate governance) w instytucjach finansowych i w przedsiębiorstwach ${ }^{33}$.

\section{PODSUMOWANIE}

Przedstawiona $\mathrm{w}$ artykule podatność przedsiębiorstw na kryzys jest zagadnieniem istotnym i ważnym z perspektywy zarządzania przedsiębiorstwem w szczególności zapobiegania kryzysom, upadłościom czy bankructwom.

Wydaje się, że warto jest poprawiać jakość mierników mogących zabezpieczyć przedsiębiorstwa przed kryzysem, czy też wyeliminować słabe strony przedsiębiorstwa zwięk-

30 J. Komorowski, Cele przedsiębiorstwa a rozwój gospodarczy. Ujęcie behawioralne, Warszawa 2012, s. 87.

${ }^{31}$ Ibidem, s. 242.

${ }^{32}$ U. Malinowska, Niematerialne mierniki zagrożenia upadtościa, Materiały i Prace, t. XCIII, Instytut Funkcjonowania Gospodarki Narodowej, Zagrożenie upadłością, Szkoła Główna Handlowa, Warszawa 2005, s. 91.

${ }^{33}$ S. Morawska, A. Czapracka, Instytucja upadtości a odpowiedzialność menadżerów - badanie polskiej praktyki sadowej na tle rozwiazań w krajach Unii Europejskiej [w:] Procesy upadtościowe i naprawcze..., s. 218. 
szając szanse jego przetrwania lub rozwoju. Narzędzia zwiększające bezpieczeństwo funkcjonowania przedsiębiorstw zwiększają ich szanse na odniesienie sukcesu i rozwoju w turbulentnym i zmiennym otoczeniu.

Zaprezentowana koncepcja podatności przedsiębiorstwa na kryzys może być punktem wyjścia do opracowania szczegółowej definicji i narzędzia diagnostycznego badającego podatność przedsiębiorstw na kryzys.

\section{LITERATURA}

[1] Barton R.M., Crisis Managament, Oxford Press Publishers, Oxford 1993.

[2] Caponigro J.R., The Crisis Counselor. A step by step Guide to Managing a Business Crisis, NTX 2000.

[3] Czerska M., Organizacja przedsiębiorstw. Metodologia zmian organizacyjnych, Wyd. UG, Gdańsk 1996.

[4] Damodaran A., Ryzyko strategiczne. Podstawy zarzadzania ryzykiem, Wydawnictwa Akademickie i Profesjonalne, Warszawa 2009.

[5] Dębicka A.H., Rozprawa doktorska pt. Zarządzanie sytuacją kryzysowa w matych i średnich przedsiębiorstwach, http://repozytorium.put.poznan.pl/Content/352778/Anna_Helena_Debicka_Zarzadzanie_sytuacja_kryzysowa_w_malych_i_srednich_przedsiebiorstwach.pdf.

[6] Gierszewska G., Strategie kryzysowe w warunkach globalizacji [w:] Praktyka zarzadzania kryzysem $w$ przedsiębiorstwie, red. B. Kozyra, A. Zelek, Wydawnictwo Zachodniopomorskiej Szkoły Biznesu, Szczecin 2002.

[7] Gruszczyński M., Empiryczne finanse przedsiębiorstw, Difin, Warszawa 2015.

[8] Hermann Ch.F., Some Consequences of Crisis chich limit The Viability of Organizations, Administrative Science Quarterly 1963, No 8.

[9] Komorowski J., Cele przedsiębiorstwa a rozwój gospodarczy. Ujęcie behawioralne, Oficyna Wydawnicza SGH w Warszawie, Warszawa 2012.

[10] Kral Z., Zabłocka-Kluczka A., O istocie zjawisk kryzysowych organizacji [w:] Zachowania organizacji wobec zjawisk kryzysowych, red. J. Skalik, Cornetis Sp. z o.o., Wrocław 2003.

[11] Malinowska U., Niematerialne mierniki zagrożenia upadłościa, Materiały i Prace, t. XCIII, Instytut Funkcjonowania Gospodarki Narodowej, „Zagrożenie upadłością”, Szkoła Główna Handlowa, Warszawa 2005.

[12] Mitroff I.I., Managing Crisises before The hapten, American Management Association, NY 2001.

[13] Morawska S., Czapracka A., Instytucja upadtości a odpowiedzialność menadżerów badanie polskiej praktyki sądowej na tle rozwiazań w krajach Unii Europejskiej [w:] Procesy upadtościowe i naprawcze w Polsce na tle doświadczeń Unii Europejskiej, red. E. Mączyńska, Oficyna Wydawnicza Szkoła Główna Handlowa w Warszawie Warszawa 2014.

[14] Oldcorn R., Management, MacMillan, London 1989.

[15] Pieńkowska M., Ujęcie upadtości w teorii przedsiębiorstwa, Materiały i Prace, t. XCII, Instytut Funkcjonowania Gospodarki Narodowej, „Ekonomiczne aspekty upadłości przedsiębiorstw w Polsce”, Szkoła Główna Handlowa, Warszawa 2005.

[16] Rochoń M., Efektywność restrukturyzacji finansowej przedsiębiorstw. Analiza komparatywna instrumentarium wspierajacego proces restrukturyzacji finansowej przedsiębiorstw na przykładzie Polski i USA, Walkowska Wydawnictwo, Szczecin 2006. 
[17] Romanowska M., Odporność przedsiębiorstwa na kryzys, Studia i prace Kolegium Zarządzania i Finansów Zeszyt naukowy 118, SGH, Warszawa 2012.

[18] Slatter S., Lovett D., Restrukturyzacja firmy. Zarządzanie przedsiębiorstwem w sytuacjach kryzysowych, WIG-Press, Warszawa 2001.

[19] Urbanowska-Sojkin E., Zarządzanie przedsiębiorstwem. Od kryzysu do sukcesu, AE Poznań, Poznań 1999.

[20] Wawrzyniak B. (red.), Zarządzanie w kryzysie. Koncepcje, badania, propozycje, PWE, Warszawa 1984.

[21] Wojtysiak-Kotlarski M., Przedsiębiorstwo a ryzyko bankructwa w kontekście doświadczeń gospodarki globalnej. Propozycja konceptualizacji ujęcia teoretycznego na tle przykładów przedsiębiorstw [w:] Procesy upadtościowe i naprawcze w Polsce na tle doświadczeń Unii Europejskiej, red.. E. Mączyńska, Oficyna Wydawnicza Szkoła Główna Handlowa w Warszawie, Warszawa 2013.

[22] Wyciślak S., Efekt zarażania a działalność organizacji, Wydawnictwo Uniwersytetu Jagiellońskiego, Kraków 2013.

[23] Zelek A., Zarzadzanie kryzysem w przedsiębiorstwie. Perspektywa strategiczna, Instytut Organizacji i zarządzania w Przemyśle „ORGMASZ”, Warszawa 2003.

[24] Zimniewicz K., Nauka o organizacji i zarzadzaniu, Wydawnictwo Naukowe PWN, Warszawa 1990.

\section{SUSCEPTIBILITY OF A COMPANY TO CRISIS - CONCEPT TO ALERT BEFORE THE THREAT OF CRISIS IN A COMPANY}

The variability of the environment contributes to the need to define a new approach to the assessment of the risks of the entity. Currently, the key is the assessment made on the basis of only one type of data (financial data) it seems to be insufficient and too much of charged with the risk of error, to define the risks of the enterprise. It is necessary to customize models and diagnostic systems to the interdisciplinary nature of the business and the opportunity to research the current situation of the company. Diagnosing bad corporate condition based on historical data is currently the optimal situation, but it can contribute to wrong management decisions of management boards of these companies as well as their stakeholders. Determining the state before the threat of bankruptcy or deterioration may help to increase the effectiveness of business decisions and sell-offs by the management of these companies and business partners. Defining the term vulnerability of the company to the crisis and the tools to evaluate the degree of vulnerability of the company to the crisis appears to be an alternative to models of risk assessment business bankruptcy, financial analysis, strategic analyzes and analyzes of sales. Creating a mechanism, which will be analyzed and diagnosed comprehensive resources of the entity taking into account the qualitative and quantitative historical perspective, the current situation of the company and its plans and opportunities in the context of the economic environment may contribute to improve quality of business management.

Keywords: business management, susceptibility to crisis, the threat of financial crisis, business crisis, the definition of susceptibility to crisis.

DOI: $10.7862 /$ rz.2017.mmr.35

Tekst złożono w redakcji: październik 2017 r.

Przyjęto do druku: grudzień 2017 r. 
